\begin{tabular}{|c|c|c|}
\hline \multirow[b]{2}{*}{ FXCFI I FI } & Int.J.Curr.Microbiol.App.Sci (2021) 10(10): 77-89 & \\
\hline & $\begin{array}{l}\text { International Journal of Current Microbiology and Applied Sciences } \\
\text { ISSN: 2319-7706 Volume } 10 \text { Number } \mathbf{1 0}(\mathbf{2 0 2 1 )} \\
\text { Journal homepage: } \underline{\text { http://www.ijcmas.com }}\end{array}$ & 30 \\
\hline PUBLISHERS & & www.ijemas.com \\
\hline
\end{tabular}

\title{
Characterization of Solanum spp for Grafting and its Interpretation on Morphological, Production and Nutritional Quality of Fruit Under Polyhouse
}

\author{
Satish Kr.Subba ${ }^{1}$, Umesh Thapa ${ }^{2}$, Pinkey Dukpa ${ }^{2}$ and Anant Tamang ${ }^{1}$ \\ ${ }^{1}$ Department of Horticulture, Centurion University of Technology and Management, \\ Odisha - 761211, India \\ ${ }^{2}$ Department of Vegetable Science, Faculty of Horticulture, Bidhan Chandra Krishi \\ Viswavidyalaya, Mohanpur - 741252, Nadia, West Bengal, India \\ *Corresponding author
}

\section{A B S T R A C T}

Keywords

Grafting, Solanum melongena, compatibility, morphological, quality and yield

Article Info

Accepted: 05 September 2021 Available Online: 10 October 2021
Seven wild Solanum species (viz., S. torvum, S. macrocapon, S. incanum, S. aethiopicum, S. sisymbrifolium, S. viarum, and $S$. indicum) were grafted onto three brinjal scions (viz., Patakata, PusaShyamla, and Bhangor) for its evaluation based on compatibility ratio and further characterization of successful graft combination for morphological, yield and quality attributing characters. On persual of grafting success percentage, Patakata and PusaShyamla grafted onto $S$. torvum had high compatibility and success rate. The species $S$. torvum exhibited better adaptability to the prevailing climate which led to more success indicating their compatibility. Complete failure on grafting was noticed in the species $S$. aethiopicum, $S$. indicum, and $S$. sisymbrifolium. The vegetative parameters were found to be maximum from the grafting combination of Patakata onto $S$. torvum, wherein PusaShyamla grafted onto $S$. torvum and $S$. macrocarpon exhibited high yield attributing characters and crop duration. Given quality parameters, the maximum values were attained from the combination of PusaShyamla and Patakata onto $S$. torvum.

\section{Introduction}

In India, West Bengal holds the highest area under brinjal cultivation i.e., 162.93 lakh hectares (NHB 2018-19, $3^{\text {rd }}$ Adv.Est.) with an annual production of 3019.00 MT. Currently, the production of brinjal is declining due to invasion by numerous pests and diseases which is not at par to feed the increasing population. Constant and repeated use of fungicides, insecticides, bactericides, and nematicides tends to pose ecological threats 
warranting safe disease management practices. At present grafting is regarded as a rapid additive tool to the relatively slow breeding methodology which is aimed at increasing environmental stress tolerance of fruit vegetables in a short duration. In addition to widely recognized advantages of disease tolerance and high crop yields, grafting technology is also highly effective in ameliorating crop losses caused by adverse environmental conditions such as low soil temperature and high salinity, especially under-protected cultivations where successive cropping or continuous farming is routinely practiced (Schwarza et al., 2010). Through the years, research in Solanum has been progressing in diverse disciplines. Thus, owing to the importance of brinjal cultivation in India and the beneficial effects incurred by grafting over wild rootstock, the present investigation entitled "Characterization of Solanum spp for grafting and its interpretation on morphological, production and nutritional quality of fruit under polyhouse".

\section{Materials and Methods}

Based on the performance of grafting success and days to graft union, the four probable rootstocks were selected and raised in a completely randomized block design with three replications using the cleft grafting method (Fig-1). Eight graft combinations using four rootstocks along with the two scions (non-grafts) were evaluated and five healthy plants of each treatment were tagged for recording data on morphological, flowering, yield, and quality parameters. Thirty days old grafts were transplanted on the raised beds with a spacing of $75 \times 60 \mathrm{~cm}$ from polybags without damaging the ball of earth. Totally twenty plants were maintained in each treatment per replication. A fertilizer dose of 100: 80: $50 \mathrm{~kg}$ of NPK per hectare was applied. No plant protection measures were adopted during the cropping period and only weeding and irrigation were undertaken. The mean data of selected plants in each replication for each genotype were subjected to analysis of variance appropriate for (CRD) completely randomized design (Panse and Sukhatme, 1957).

TSS was determined by a digital refractometer and expressed in ${ }^{\circ}$ Brix. Total sugars were estimated as per (Dubois et al., 1956). Anthocyanin content in the peel of the fruit was estimated spectrophotometrically by taking peel tissue (Srivastava and Kumar, 2002). Fresh fruits were collected from the third harvesting of the crop from each genotype in each replication. For estimation of vitamin C, the procedure proposed by (Sadasivam and Balasubraminan, 1987) was followed. Vitamin-C (mg/100g) content was measured as (Dye Factor Value $\times$ Titrate Value $\times$ Volume make up $\times 100) /($ Aliquot took $\times$ Weight of the sample), where, Dye Factor Value $=0.5 /$ Titrate reading $(\mathrm{ml})$.

\section{Results and Discussion}

\section{Days to germination and germination percentage}

Based on the performance of different species, S. torvum (T3) took a minimum (8.75 days) to germinate followed by $S$. macrocarpon (T1) (10.57 days), however the maximum number of days for germination were recorded from $S$. viarum (T5) (42 days) (Table-1). Concerning to germination percentage at $15 \mathrm{DAS}$, the maximum values was obtained from $S$. macrocarpon (T1) (85.89\%) and S. torvum (T3) (80.99\%), whereas at 25 DAS, $S$. sisymbrifolium(T2) had the highest germination percentage $(87.26 \%)$ next to $S$. macrocarpon (T1) $(91.78 \%)$. On perusal of different species, $S$. sisymbrifolium though germinated later than $S$. torvum picked up its germination percentage equivalent to its predecessors at 25 DAS. Similar findings were 
reported by (Ibrahim et al., 2001) who revealed that $S$. sisymbrifolium had the highest germination percentage compared to other wild Solanumspecies in the later stages of a crop growth cycle.

\section{Days for the graft union}

Among the seven rootstocks used for grafting, the species $S$. torvum took the least number of days for graft union with Patakata $\left(\mathrm{T}_{1}\right)(10.20$ days) followed by PusaShyamla $\left(\mathrm{T}_{8}\right)$ (11.04 days) and Bhangor ( $\left.1_{5}\right)$ (11.95 days) whereas, S. sisymbrifolium took maximum number of days for union with Bhangor $\left(\mathrm{T}_{21}\right)$ (24.05 days) through cleft grafting method (Table-2). This is a characteristic of graftrootstock incompatibility, which contributes to poor vascular connection with poor connecting sieve tubes, cambium, and xylem in tomato on pepper and pepper on tomato grafts (Kawaguchi et al., 2008).

\section{Grafting success percentage}

Among all the grafts combination, Patakata grafted onto $S$. $\operatorname{torvum}\left(\mathrm{T}_{1}\right)$ recorded the highest success percentage of 91.33 per cent on $15^{\text {th }}$ DAG, 82.22 percent on $30^{\text {th }} \mathrm{DAG}$ and 77.20 percent on $45^{\text {th }}$ DAG (Table-2). The species $S$. torvum had better adaptability to the prevailing climate which led to more success and the cleft grafting method suited more for this species, which is in agreement with the report of Feng et al., (2000). The lowest success percentage of (22.11 percent) at $15^{\text {th }}$ DAG, (0.00 percent) at $30^{\text {th }}$ DAG, and $(0.00$ percent) at $45^{\text {th }}$ DAG was recorded from the graft combination of Bhangor onto $S$. $\operatorname{viarum}\left(\mathrm{T}_{19}\right)$. Complete failure on grafting was noticed in the species $S$. aethiopicum, $S$. indicum and $S$. sisymbrifolium with three brinjal scions at 45DAG which be due to lack of cellular recognition, wounding responses, presence of growth regulators or incompatible toxins, or an unfavorable grafting environment which is in agreement with (Davis et al., 2008). Among the three brinjal scions employed in this study, PusaShyamla and Patakata showed relatively higher grafting success compared to Bhangor.

\section{Evaluation of grafts for growth, yield and qualitative parameters}

Based on the performance of grafting success and days to graft union, the probable rootstocks viz., $S$. torvum, $S$. macrocarpon, $S$. incanum and $S$. viarum and two scions viz., Patakata and PusaShyamla were selected and used for the study of morphological, production, and quality characters.

\section{Vegetative parameters}

The pooled data revealed that Patakata grafted on $S$. torvum was found to be the best for plant height, the number of leaves and total number of branches at different stages of plant growth. The grafted plants exhibited no significant difference for vegetative parameters. Among all the graft combinations, the two non-grafts, Patakata recorded the highest plant height $(17.05,38.12,71.72$, and $85.32 \mathrm{~cm}$ at 30,60 , 90, 120 DAT) whereas, the lowest plant height $(12.71,34.02,66.91$, and $73.77 \mathrm{~cm}$ at 30,60 , 90, 120 DAT)was recorded from graft combination of PusaShyamla and $S$. viarum (Table-3). It has been reported that the plant hormones are important endogenous factors that regulate all aspects of vegetative growth in root-shoot communication (Aloni et al., 2010) The low performance of other scionrootstock compared to Patakata grafted onto $S$. torvum rootstock is justified by unsuitable graft relations that can induce undergrowth or overgrowth of the scion, which can lead to decreased water and nutrient flow through the graft union (Martinez-Ballesta et al., 2010). The maximum number of leaves at different stages of crop growth viz., (31.98, 83.06, 141.99 and 144.81 at 30, 60, 90, 120 DAT) 
was obtained from graft combination of Patakata and $S$. torvum, which was statistically at parwith PusaShyamla grafted onto S.torvum and $S$. macrocarpon (Table-3).

When compared to non-grafted plants, maximum number of total branches per plant was registered from Patakata grafted onto $S$. torvum (5.02, 11.85, 14.67 and 16.78 at 30, 60, 90, 120 DAT) and $S$. macrocarpon. The vigorous root system of the rootstock enhanced better growth of scion which resulted in more number of branches in grafted plants (Davis et al., 2006). Grafting caused an increase in leaf area and leaf area index wherein Patakata grafted onto $S$. torvum recorded the highest leaf area index of (2.29) followed by PusaShyamla grafted onto $S$. torvum(2.24) (Table-4).

\section{Flowering and fruiting parameters}

The number of flowers was significantly influenced by different graft combinations during the experimental years. The maximum number of flowers per plant at different stages of plant growth was registered from PusaShyamla grafted onto S. torvum(11.69, 94.29, 78.33, and 47.82 at 30, 60, 90, and 120 DAT) wherein Patakata grafted onto $S$. viarum recorded minimum number of flowers at different growth stages $(7.00,72.75,65.92$, 37.00at 30, 60, 90 and 120 DAT) (Table-4).

These results agreed with the findings of Eltayb et al., (2013) who reported that grafting has the ability to influence and change leaf and flowers morphology of eggplant and pepper. Days to first fruit set and days to the first harvest is directly influenced by earliness in flowering where non-grafts PusaShyama and Patakata started to set fruit within 58.87 to 73.52 days after sowing. Among all the graft combination, the fruit set was noticed earlier from PusaShyamla grafted onto $S$. torvum (64.44 days) followed by Patakata onto
S.torvum (66.04days). Vigorous plants by grafting extended the growth period and luxurious growth and delayed flowering and fruit set. (Table-5). Compared to grafted plants, non-grafted plant PusaShyamla (81.43 days) showed earlier fruit harvest whereas among the eight graft combinations, early fruit harvest was noticed in PusaShyamla grafted onto S. torvum (86.87 days) followed by Patakata onto $S$. torvum(88.01 days). The graft combinations of Patakata onto $S$. viarum took the highest number of days to first harvest (99.82 days). The earliness in fruit harvest might be due to hormonal signaling in rootstock-scion interactions which have a greater impact on flowering and fruit setting. Similar findings were observed by Sanjeev et $a l .$, (2016) in grafted brinjal plants.

Respective non-grafted plants Patakata recorded the highest fruit length $(22.67 \mathrm{~cm})$ and diameter $(5.68 \mathrm{~cm})$ than the grafted plants. Among the eight graft combinations the highest fruit length was noticed in Patakata grafted onto S.torvum $(22.53 \mathrm{~cm})$ and $S$. macrocarpon $(21.36 \mathrm{~cm})($ Table-5). This might be due to the superior nature of particular cultivar and size of the fruit was negatively correlated with number of fruits. The same results have been put forward by Mohammed et al., (2009) who found that the fruit size of the grafted tomato was not greater than the fruit size of the non-grafted plants.

\section{Crop duration}

Crop duration was calculated from the date of transplanting wherein PusaShyamla grafted onto S.torvum and S. incanum recorded longer crop duration(194.89 and 182.91 days).

The pooled data revealed that shorter crop duration was recorded from non-grafts, Patakata (156.40 days) followed by PusaShyamla (159.38 days) (Table-5). 
Table.1 Performance of wild Solanum species on days to germination and germination percentage

\begin{tabular}{|c|l|c|c|c|}
\hline \multicolumn{2}{|c|}{ Treatments } & Days to germination & \multicolumn{2}{c|}{ Germination \% } \\
\cline { 3 - 5 } & & 15DAS & 25DAS \\
\hline T1 & S. macrocarpon & 10.57 & 85.89 & 91.78 \\
\hline T2 & S. sisymbrifolium & 12.35 & 61.58 & 87.26 \\
\hline T3 & S. torvum & 8.75 & 80.99 & 85.32 \\
\hline T4 & S. incanum & 11.50 & 69.55 & 79.97 \\
\hline T5 & S. viarum & 15.42 & 51.18 & 55.25 \\
\hline T6 & S. indicum & 12.72 & 47.49 & 53.48 \\
\hline T7 & S. aethiopicum & 14.75 & 41.61 & 46.56 \\
\hline \multicolumn{2}{r|}{ SE(d) } & 0.31 & 1.49 & 1.58 \\
\hline & CD(P=0.05) & 0.67 & 3.22 & 3.42 \\
\hline
\end{tabular}

Fig.1 Steps in Cleft grafting
(A)
(B)
(C)
(D)

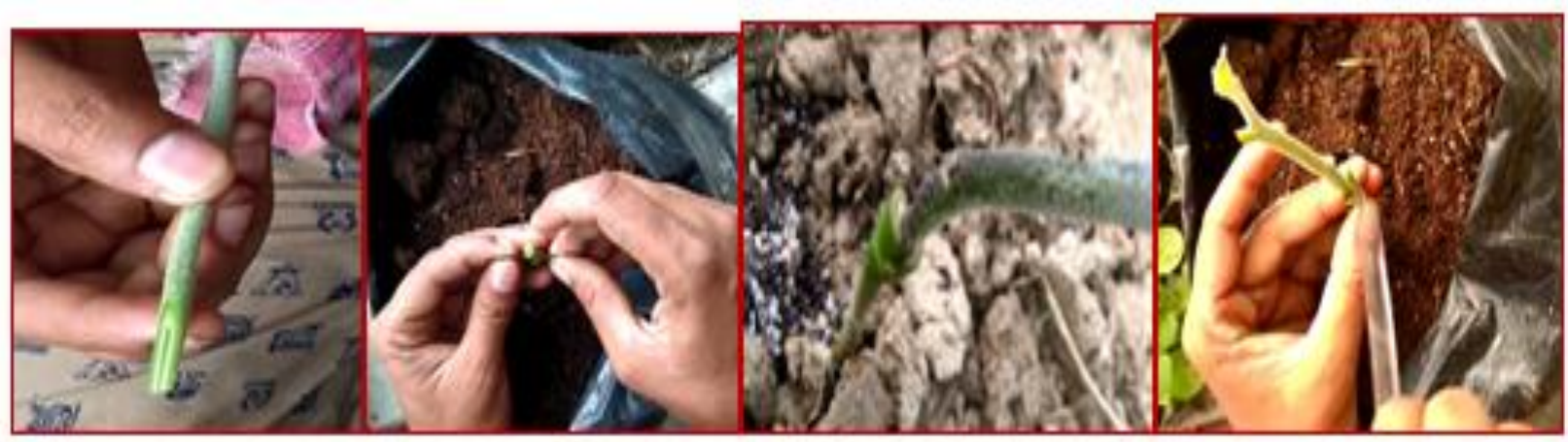

(E)

(F)

(G)

(H)

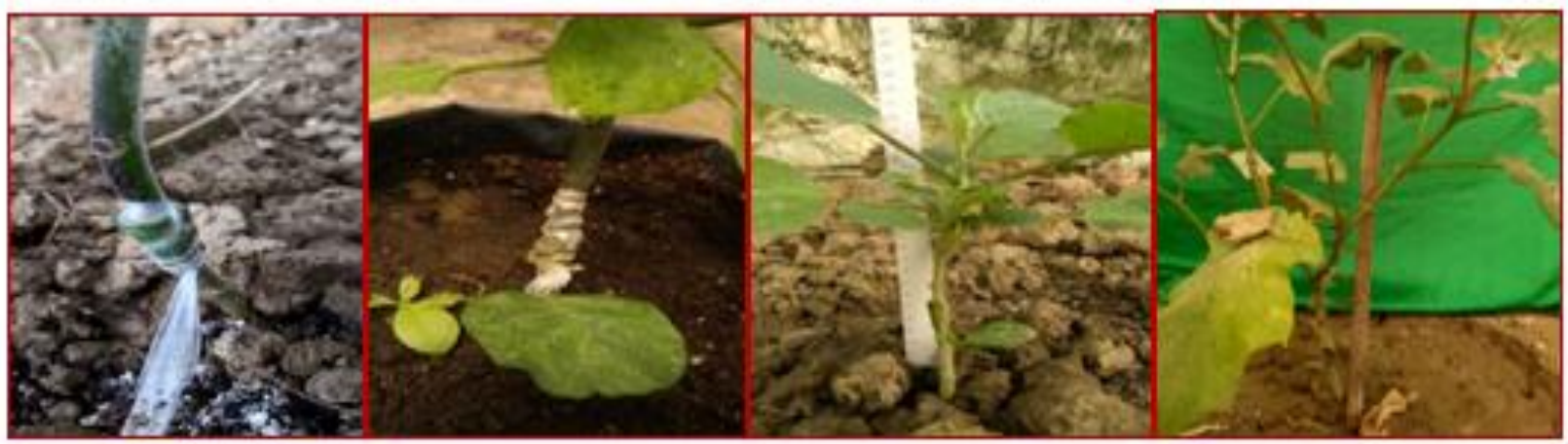

(A) Scion preparation (wedge shaped), (B) Stock preparation, (C) Insertion, (D) Wrapping with polypropylene sheets, (E) Grafted plant, (F) Graft union, ( G) Successful grafts inside polyhouse, (H) Grownup grfated palnt 
Table.2 Performance of graft combinations on grafting success percentage and days for graft union

\begin{tabular}{|c|c|c|c|c|c|}
\hline \multicolumn{5}{|c|}{ Grafting success percentage } & \multirow{3}{*}{$\begin{array}{c}\text { Days for graft union } \\
10.20\end{array}$} \\
\hline \multicolumn{2}{|r|}{ Treatments } & 15 DAG & 30DAG & 45 DAG & \\
\hline $\mathbf{T 1}$ & Patakata on S. torvum & $91.33(9.58)$ & $82.22(9.10)$ & $77.20(8.81)$ & \\
\hline $\mathbf{T} 2$ & Patakata on $S$. incanum & $83.14(9.15)$ & $71.18(8.45)$ & $68.25(8.29)$ & 13.63 \\
\hline T3 & Patakata on S. macrocarpon & $86.71(9.33)$ & $77.37(8.82)$ & $73.84(8.62)$ & 11.38 \\
\hline T4 & Patakata on S. aethiopicum & $39.44(6.31)$ & $8.89(3.06)$ & $0.00(0.71)$ & 19.61 \\
\hline T5 & Patakata on S. viarum & $68.93(8.33)$ & $65.07(8.10)$ & $63.07(7.97)$ & 15.58 \\
\hline T6 & Patakata on S. indicum & $47.64(6.94)$ & $12.24(3.57)$ & $0.00(0.71)$ & 17.49 \\
\hline T7 & Patakata on $S$. sisymbrifolium & $35.84(6.03)$ & $0.00(0.71)$ & $0.00(0.71)$ & 20.40 \\
\hline T8 & PusaShyamla on S. torvum & $84.84(9.24)$ & $76.61(8.78)$ & $72.40(8.54)$ & 11.04 \\
\hline T9 & PusaShyamla on $S$. incanum & $77.36(8.82)$ & $70.52(8.43)$ & $61.48(7.87)$ & 14.62 \\
\hline T10 & PusaShyamla on $S$. macrocarpon & $81.32(9.05)$ & $75.48(8.72)$ & $67.48(8.24)$ & 13.38 \\
\hline T11 & PusaShyamla on S. aethiopicum & $35.12(5.97)$ & $6.63(2.67)$ & $0.00(0.71)$ & 20.05 \\
\hline T12 & PusaShyamla on S. viarum & $64.21(8.04)$ & $60.33(7.80)$ & $58.45(7.68)$ & 16.78 \\
\hline T13 & PusaShyamla on $S$. indicum & $41.93(6.51)$ & $25.47(5.10)$ & $0.00(0.71)$ & 18.59 \\
\hline T14 & PusaShyamla on S. sisymbrifolium & $28.36(5.37)$ & $0.00(0.71)$ & $0.00(0.71)$ & 21.74 \\
\hline T15 & Bhangor on S. torvum & $75.82(8.74)$ & $74.24(8.65)$ & $66.58(8.19)$ & 11.95 \\
\hline T16 & Bhangor on S. incanum & $65.35(8.11)$ & $70.11(8.40)$ & $60.66(7.82)$ & 15.97 \\
\hline T17 & Bhangor on S. macrocarpon & $61.66(7.88)$ & $54.66(7.43)$ & $57.21(7.60)$ & 14.15 \\
\hline T18 & Bhangor on S. aethiopicum & $30.48(5.57)$ & $5.66(2.48)$ & $0.00(0.71)$ & 23.22 \\
\hline T19 & Bhangor on S. viarum & $22.11(5.35)$ & $0.00(0.71)$ & $0.00(0.71)$ & 20.17 \\
\hline T20 & Bhangor on $S$. indicum & $40.58(6.41)$ & $25.12(5.06)$ & $0.00(0.71)$ & 20.99 \\
\hline \multirow[t]{3}{*}{ T21 } & Bhangor on S. sisymbrifolium & $28.11(5.35)$ & $0.00(0.71)$ & $0.00(0.71)$ & 24.05 \\
\hline & SE $(d)$ & 1.42 & 1.29 & 1.91 & 0.35 \\
\hline & $\mathrm{CD}(\mathrm{P}=0.05)$ & 2.88 & 2.61 & 2.41 & 0.72 \\
\hline
\end{tabular}

*DAG-Days after grafting. Figures in parentheses are square root $(\mathrm{X}+0.5)$ transformed values 
Table.3 Performance of graft combinations and non-grafts for plant height, Number of leaves and Total no. of branches.

\begin{tabular}{|c|c|c|c|c|c|c|c|c|c|c|c|c|c|}
\hline \multicolumn{6}{|c|}{ Plant height } & \multicolumn{4}{|c|}{ Number of leaves } & \multicolumn{4}{|c|}{ Total no. of branches } \\
\hline \multicolumn{2}{|r|}{ Treatments } & 30 & 60 & 90 & & & 60 & 90 & 120 & 30 & 60 & 90 & 120 \\
\hline T1 & PusaShyamla on $S$. torvum & 18.77 & 46.64 & 76.60 & 87.26 & 28.43 & 79.31 & 137.42 & 142.09 & 4.30 & 10.37 & 13.93 & 15.94 \\
\hline $\mathbf{T 2}$ & PusaShyamlaonS. incanum & 14.08 & 37.32 & 70.31 & 77.18 & 24.38 & 73.82 & 102.19 & 107.44 & 3.05 & 7.94 & 11.04 & 11.94 \\
\hline T3 & $\begin{array}{l}\text { PusaShyamla on } S \text {. } \\
\text { macrocapon }\end{array}$ & 16.07 & 43.34 & 75.57 & & 26.53 & 76.69 & & 123.92 & 3.62 & 9.48 & & 14.35 \\
\hline T4 & PusaShy & 2.71 & 34.02 & 66.91 & 73.77 & 20.83 & 68.52 & 90.02 & 101.31 & 2.94 & 7.42 & 9.41 & 10.13 \\
\hline T5 & Patakata & 19.87 & 49.66 & 80.30 & 89.72 & 31.98 & 83.06 & 141.99 & 144.81 & 5.02 & 11.85 & 14.67 & 16.78 \\
\hline T6 & & 17.51 & 40.32 & 73.36 & 84.15 & 26.84 & 76.11 & & 112.08 & 3.74 & 9.85 & 12.84 & 14.09 \\
\hline T7 & Patak & 17.87 & 43.52 & 77.21 & 85.38 & 30.20 & 78.41 & 126.01 & 128.95 & 4.52 & 11.13 & 13.79 & 15.10 \\
\hline T8 & & 16.35 & 38.80 & 71.93 & 82.76 & 25.63 & 74.36 & & 110.87 & 3.20 & 8.57 & 11.32 & 11.41 \\
\hline T9 & PusaShya & 14.80 & 33.84 & 67.72 & 80.38 & 24.04 & 68.07 & 76.16 & 89.73 & 3.34 & 6.91 & 12.35 & 13.58 \\
\hline T10 & Patakata & 17.05 & 38.12 & 71.72 & 85.32 & 26.03 & 73.66 & 82.90 & 94.89 & 3.90 & 7.98 & 13.60 & 14.83 \\
\hline & & 0.39 & 0.77 & 1.50 & 1.59 & 0.62 & 1.71 & 2.04 & 2.40 & 0.08 & 0.22 & 0.23 & 0.28 \\
\hline & $\mathrm{CD}(\mathrm{P}=0.05)$ & 0.83 & 1.61 & 3.16 & 3.33 & 1.30 & 3.59 & 4.29 & 5.05 & 0.18 & 0.47 & 0.49 & 0.60 \\
\hline
\end{tabular}


Table.4 Performance of graft combinations and non-grafts for number of flowers, Days to $1^{\text {st }}$ flowering, Days taken for $50 \%$ flowering, Leaf Area $\left(\mathrm{cm}^{2}\right)$ and LAI.

\begin{tabular}{|c|c|c|c|c|c|c|c|c|c|}
\hline \multicolumn{6}{|c|}{ Number of flowers } & \multirow{2}{*}{$\begin{array}{l}\text { Days to } 1^{\text {st }} \\
\text { flowering }\end{array}$} & \multirow{2}{*}{$\begin{array}{c}\text { Days } \\
\text { taken for } \\
50 \% \\
\text { flowering }\end{array}$} & \multirow{2}{*}{$\begin{array}{l}\text { Leaf Area } \\
\qquad\left(\mathrm{cm}^{2}\right)\end{array}$} & \multirow[t]{2}{*}{ LAI } \\
\hline & Treatments & 30 & 60 & 90 & 120 & & & & \\
\hline $\mathbf{T 1}$ & PusaShyamla on S. torvum & 11.69 & 94.29 & 78.33 & 47.82 & 56.44 & 59.90 & 160.87 & 2.24 \\
\hline $\mathbf{T} 2$ & PusaShyamlaonS. incanum & 8.62 & 77.90 & 68.96 & 40.72 & 60.84 & 68.21 & 155.08 & 2.05 \\
\hline T3 & $\begin{array}{l}\text { PusaShyamla on } S \text {. } \\
\text { macrocapon }\end{array}$ & 10.09 & 86.95 & 73.81 & 43.84 & 59.82 & 65.78 & 158.42 & 2.12 \\
\hline T4 & PusaShyamla on $S$. viarum & 8.29 & 75.04 & 59.40 & 38.04 & 63.43 & 71.16 & 151.58 & 1.86 \\
\hline T5 & Patakata on S. torvum & 10.95 & 93.89 & 76.43 & 43.95 & 57.90 & 63.69 & 169.28 & 2.29 \\
\hline T6 & Patakata on S. incanum & 7.08 & 75.64 & 69.38 & 37.85 & 63.04 & 70.73 & 165.05 & 1.95 \\
\hline T7 & Patakata on S. macrocapon & 8.64 & 85.41 & 73.25 & 41.21 & 60.45 & 67.67 & 167.22 & 2.12 \\
\hline T8 & Patakata on $S$. viarum & 7.00 & 72.75 & 65.92 & 37.00 & 65.78 & 71.79 & 160.30 & 2.02 \\
\hline T9 & PusaShyamla & 8.96 & 89.37 & 77.30 & 45.16 & 50.94 & 56.42 & 146.30 & 1.84 \\
\hline T10 & Patakata & 8.05 & 74.03 & 63.84 & 39.99 & 52.76 & 59.07 & 149.81 & 1.91 \\
\hline & SE $(d)$ & 0.22 & 1.92 & 1.60 & 0.95 & 1.29 & 1.42 & 3.56 & 0.05 \\
\hline & $\mathrm{CD}(\mathrm{P}=0.05)$ & 0.46 & 4.02 & 3.36 & 1.99 & 2.71 & 2.97 & 7.49 & 1.10 \\
\hline
\end{tabular}

*Days taken for $\mathbf{1}^{\text {st }}$ flowering, Days taken for $50 \%$ flowering were calculated from the date of sowing. 
Table.5 Performance of graft combinations and non-grafts for Days to $1^{\text {st }}$ fruit set, Days to $1^{\text {st }}$ harvest, Fruit length (cm), Fruit diameter $(\mathrm{cm})$, Crop duration, Number of fruits per plant, Average fruit weight (g/fruit), and Fruit yield (kg/plant).

\begin{tabular}{|c|c|c|c|c|c|c|c|c|c|}
\hline \multicolumn{2}{|r|}{ Treatments } & \multirow{2}{*}{$\begin{array}{c}\begin{array}{c}\text { Days to } \\
\mathbf{1}^{\text {st }} \begin{array}{c}\text { fruit } \\
\text { set }\end{array}\end{array} \\
64.44 \\
\end{array}$} & \multirow{2}{*}{$\begin{array}{c}\begin{array}{c}\text { Days to } \\
\mathbf{1}^{\text {st }}\end{array} \\
\text { harvest } \\
86.87 \\
\end{array}$} & \multirow{2}{*}{$\begin{array}{c}\begin{array}{c}\text { Fruit } \\
\text { length } \\
\text { (cm) }\end{array} \\
18.59 \\
\end{array}$} & \multirow{2}{*}{$\begin{array}{c}\begin{array}{c}\text { Fruit } \\
\text { diameter } \\
(\mathbf{c m})\end{array} \\
5.08\end{array}$} & \multirow{2}{*}{$\begin{array}{c}\begin{array}{c}\text { Crop } \\
\text { duration }\end{array} \\
194.89 \\
\end{array}$} & \multirow{2}{*}{$\begin{array}{c}\begin{array}{c}\text { Number } \\
\text { of fruits } \\
\text { per plant }\end{array} \\
21.06 \\
\end{array}$} & \multirow{2}{*}{$\begin{array}{c}\text { Average } \\
\text { fruit } \\
\text { weight } \\
\text { (g/fruit) } \\
123.93 \\
\end{array}$} & \multirow{2}{*}{$\begin{array}{c}\begin{array}{c}\text { Fruit } \\
\text { yield } \\
\text { (kg/plant) }\end{array} \\
2.62 \\
\end{array}$} \\
\hline $\mathbf{T 1}$ & PusaShyamla on S. torvum & & & & & & & & \\
\hline $\mathbf{T} 2$ & PusaShyamla on $S$. incanum & 70.10 & 93.83 & 17.98 & 4.72 & 182.91 & 17.34 & 118.74 & 2.06 \\
\hline T3 & $\begin{array}{l}\text { PusaShyamla on } S \text {. } \\
\text { macrocapon }\end{array}$ & 68.96 & 92.37 & 18.27 & 4.92 & 177.46 & 19.04 & 119.50 & 2.28 \\
\hline T4 & PusaShyamla on $S$. viarum & 73.43 & 97.12 & 16.37 & 4.69 & 180.77 & 16.08 & 116.89 & 1.88 \\
\hline T5 & Patakata on S. torvum & 66.04 & 88.01 & 22.53 & 5.46 & 171.93 & 18.12 & 128.17 & 2.32 \\
\hline T6 & Patakata on $S$. incanum & 72.92 & 95.29 & 19.23 & 5.00 & 160.58 & 15.78 & 121.83 & 1.92 \\
\hline T7 & Patakata on S. macrocapon & 69.69 & 93.87 & 21.36 & 5.18 & 158.43 & 17.04 & 124.30 & 2.16 \\
\hline T8 & Patakata on $S$. viarum & 73.52 & 99.82 & 18.57 & 4.95 & 158.64 & 15.17 & 119.05 & 1.81 \\
\hline T9 & PusaShyamla & 58.87 & 81.43 & 20.92 & 5.35 & 159.38 & 17.54 & 127.10 & 2.23 \\
\hline T10 & Patakata & 61.27 & 82.81 & 22.67 & 5.68 & 156.40 & 16.22 & 132.96 & 2.12 \\
\hline & $\operatorname{SE}(d)$ & 1.48 & 1.98 & 0.47 & 0.12 & 3.82 & 0.56 & 2.40 & 0.07 \\
\hline & $\mathrm{CD}(\mathrm{P}=0.05)$ & 3.11 & 4.16 & 0.99 & 0.25 & 8.03 & 1.18 & 5.03 & 0.14 \\
\hline
\end{tabular}

Days to $1^{\text {st }}$ fruit set and Days to ${ }^{\text {st }}$ harvest were calculated from the date of sowing.

$* *$ Crop duration is from the date of transplanting. 
Table.6 Performance of graft combinations and non-grafts for quality parameters.

\begin{tabular}{|c|c|c|c|c|c|c|}
\hline \multicolumn{2}{|r|}{ Treatments } & \multirow{2}{*}{$\begin{array}{c}\left.\text { TSS ( }{ }^{\mathbf{0}} \text { Brix }\right) \\
5.16\end{array}$} & \multirow{2}{*}{$\begin{array}{c}\text { Titratable } \\
\text { acidity (\%) } \\
0.66\end{array}$} & \multirow{2}{*}{$\begin{array}{c}\text { Anthocyanin in peel } \\
\left(\mathbf{m g ~ g}^{-\mathbf{1}}\right)\end{array}$} & \multirow{2}{*}{$\begin{array}{c}\text { Total } \\
\text { Sugar }(\%) \\
1.72\end{array}$} & \multirow{2}{*}{$\begin{array}{c}\begin{array}{c}\text { Vit. C } \\
\left(\mathbf{m g ~ g}^{-1}\right)\end{array} \\
0.115\end{array}$} \\
\hline T1 & PusaShyamla on S. torvum & & & & & \\
\hline $\mathbf{T} 2$ & PusaShyamla on $S$. incanum & 4.90 & 0.60 & 5.84 & 1.64 & 0.110 \\
\hline T3 & PusaShyamla on $S$. macrocapon & 4.98 & 0.64 & 6.49 & 1.67 & 0.112 \\
\hline T4 & PusaShyamla on $S$. viarum & 4.82 & 0.57 & 5.73 & 1.59 & 0.108 \\
\hline T5 & Patakata on $S$. torvum & 5.18 & 0.58 & 5.71 & 1.68 & 0.112 \\
\hline T6 & Patakata on $S$. incanum & 4.89 & 0.53 & 5.72 & 1.61 & 0.105 \\
\hline T7 & Patakata on $S$. macrocapon & 4.76 & 0.56 & 5.49 & 1.65 & 0.109 \\
\hline T8 & Patakata on $S$. viarum & 4.67 & 0.50 & 4.71 & 1.53 & 0.100 \\
\hline T9 & PusaShyamla & 4.85 & 0.61 & 5.88 & 1.66 & 0.111 \\
\hline \multirow[t]{3}{*}{ T10 } & Patakata & 4.74 & 0.48 & 5.17 & 1.63 & 0.107 \\
\hline & $\mathrm{SE}(\mathrm{d})$ & N.A & 0.01 & 0.42 & 0.04 & 0.006 \\
\hline & $\mathrm{CD}(\mathrm{P}=\mathbf{0 . 0 5})$ & 0.21 & 0.03 & 0.89 & 0.08 & 0.013 \\
\hline
\end{tabular}


The possible reason for longer crop duration is that grafting takes a longer time in forming a compatible union between stock and scion, which ultimately delayed the vegetative and reproductive growth stages of a plant. Rashid et al., (2005) and Sherly, (2011) also stated that harvest duration was about one month longer when eggplant was grafted to $S$. torvum.

\section{Yield parameters}

Brinjal scion grafted onto rootstock Solanum torvum showed the maximum number of fruits and higher fruit weight due to increase in the xylem sap and hormone concentrations. The number of fruits per plant had a strong relationship in increasing the yield of a crop where more number of fruits produced by any kind of vegetable is a direct indicator of high yield (Table-5). More number of fruits per plant was noticed from PusaShyamla grafted onto $S$. torvum(21.06) and S. macrocarpon (19.04). Perez et al., (2006) also observed that number of fruits per plant was high in grafted tomato plants than in self-grafted plant. The maximum average fruit weight during the experimental years was registered from Patakata grafted onto $S$. torvum $(128.17 \mathrm{~g})$ and $S$. macrocarpon $(124.30 \mathrm{~g})$. This might be due size (length and diameter) of the fruit being positively correlated with the weight of the fruit.

\section{Fruit yield (kg/plant)}

Among the eight graft combinations, PusaShyamla grafted onto $S$. torvum and $S$. macrocarpon recorded maximum fruit yield (2.62 and $2.28 \mathrm{~kg} /$ plant) (Table-5). The graft combination of Patakata onto $S$. Viarum recorded minimum fruit yield $(1.81 \mathrm{~kg} /$ plant $)$ which was on par with PusaShyamla onto $S$. viarum $(1.88 \mathrm{~kg} /$ plant $)$. Among the two brinjal plants (non-grafted), PusaShyamla had the maximum fruit yield $(2.23 \mathrm{~kg} / \mathrm{plant})$ than
Patakata (2.12 kg/plant). Compared to four different rootstocks, grafts on $S$. torvum and $S$. macrocarpon used as rootstocks showed more number of fruits and fruit yield per plant than $S$. incanum and $S$. viarum. These findings corroborate with the earlier results of Alexios et al., (2007) who reported that in plants irrespective of rootstock the fruit yield was significantly higher in the grafted plants than in the non-grafted control.

\section{Quality parameters}

The quality parameters (Total soluble solids, Titrable acidity, Anthocyanin, Vit C, and Total sugar) were found to be significantly influenced by grafting. The highest TSS and Titrable acidity were recorded from PusaShyamla grafted onto $S$. torvum(5.16 ${ }^{\circ}$ Brix and $0.66 \%$ ), which was on par with PusaShyamla grafted onto $S$. macrocarpon $\left(4.98^{\circ}\right.$ Brix and $0.64 \%$ ) and respective non-grafts.

The experimental findings revealed that grafting may have positive effects on acidity of the brinjal fruits produced. These results were under study of earlier workers, Turhan et al., (2011) who reported that suitable rootstock improved the titratable acidity value of grafted tomato plants. The results on anthocyanin content and total sugar in brinjal fruits also showed that the grafting significantly promoted the anthocyanin content in peel of brinjal fruits, compared to respective non-grafts (Table-6). The lowest anthocyanin value was noticed in Patakata grafted onto S.viarum(4.71 $\mathrm{mg} \mathrm{g}^{-1}$ ). The highest value of total sugar was observed from PusaShyamla grafted onto S. torvum (1.72\%), S. macrocarpon $(1.67 \%)$ and S. incanum (1.64 $\%)$. PusaShyamla and Patakata when grafted onto $S$. viarum exhibited the lowest value of total sugar (1.59 and $1.53 \%$ respectively). These could visualize that the dominance of scion over rootstock in an expression of 
quality as true to the type of its originality. The highest Vit-C content was recorded from PusaShyamla grafted onto $S$. torvum $(0.115 \mathrm{mg}$ $\left.\mathrm{g}^{-1}\right)$ and $S$. macrocarpon $\left(0.112 \mathrm{mg} \mathrm{g}^{-1}\right)$. Among the two non-grafts, PusaShyamla had more- Vit-C content $\left(0.111 \mathrm{mg} \mathrm{g}^{-1}\right)$ than Patakata $\left(0.107 \mathrm{mg} \mathrm{g}^{-1}\right)$ (Table-6). The results indicated that grafting had a positive effect on quality parameters (Vit-C and Titrable acidity) Liu Na et al., 2012.

The probable rootstocks viz., S. torvum, $S$. macrocarpon, $S$. incanum and $S$. viarumwas selected based on promising compatibility and high success percentage with two scions viz., Patakata and PusaShyamla. Complete failure on grafting was noticed in the species $S$. aethiopicum, $S$. indicum, and $S$. sisymbrifolium with three brinjal scions at 45DAG due to lack of cellular recognition, wounding responses, presence of growth regulators or incompatible toxins or an unfavorable grafting environment. Among all the graft combinations PusaShyamla grafted onto $S$. torvum and $S$. macrocarpon gave better field performance vis a vis quality and yield.

\section{Acknowledgements}

The first author sincerely acknowledge Ministry of Tribal Affairs, Government of India with the financial assistance through NFST fellowship.

\section{References}

Alexios, A., Alexopoulos, Angelos, K. and Harold, C. P. 2007. Fruit yield and quality of watermelon in relation to grafting. J. of Food, Agri. and Env., 5(1): 178-179.

Ali, M., Alam, M. Z. and Akanda, M. A. M. 1994. Grafting: A technique of control soil- borne disease of tomato and eggplant. IPSA-JICA Pub. No.4.
Institute of Post Graduate studies in Agriculture (IPSA), Gazipur- 1703. Bangladesh, pp.10.

Aloni, B., Cohen, R., Karni, L., Aktas, H. and Edelstein, H. 2010. Hormonal signaling in rootstock-scion interactions.Hort. Sci., 127: 119-126.

Area and Production of horticultural crops for 2018-19 (3 ${ }^{\text {rd }}$ Advance Estimates). nhb.gov.in/statistics.

Davis, A. R., Perkins-Veazie, P., Hassell, R., King, S. R. and Xingpin, Z. 2008. Grafting effects on vegetable quality. Hort Sci., 43 (6):1679-1672.

Dubois, M., Gilles, K. A., Hamilton, J. K., Robers, P. A. and Smith, F. 1956.A colorimetric method for the determination of sugar. Anal. Chem., 28: 350-56.

Eltayb, M. T. A., Magid, T. D. A., Ahmed, R. M. and Ibrahim, A. A. 2013. Morphological changes on scions due to grafting eggplant and pepper onto tomato rootstock. J. of Forest Products and Ind., 2(5): 2325-4513(print), 2325453 (online).

Feng, D. X., Li, B. D. and Wang, Y. 2000. Effects of grafting on the resistance to Verticillium wilt and on the biological characteristics of eggplant. China Veg., 4:13-15.

Ibrahim, M., Munira, M. K., Kabir, M. S., Islam, A. K. M. S. and Miah, M. M. U. 2001. Seed germination and graft compatibility of Wild Solanum as roots to stock of Tomato. Online J. of Bio.Sci.. 1(8):701-703.

Kawaguchi, M., A. Taji, D. Backhouse and M. Oda. 2008. Anatomy and physiology of graft incompatibility in solanaceous plants. 2008. J. of Hort. Sci. Biotech., 83 (5): 581-588.

Liu Na, Zhou Bao-li, Hao Jing, Lu Bo and Zhu Wei-min. 2012.Biological characteristics of grafted eggplant on tomato rootstocks. African J. of Agri. 
Res., 7(18):2791-2799.

Madhur, K. T, Anand, K. S, Singh, B. K. and Rai, V. K. 2009.Genetic variability, heritability and genetic advances among different quantitative characters of brinjal. Haryana J. of Hort. Sci., 38(3):334-35.

Martinez-Ballesta, M. C., Alcaraz- Lopez, C., Muries, B., Mota-Cadenas, C. and Carvajal, M. 2010. Physiological aspects of rootstock-scion interactions. Scientia Hort., 127:112-118.

Matsuzoe, N., Nakamura, H., Okuba, H. and Fujieda, K. 1990. Growth behavior of tomato plants grafted on wild relatives of Solanum melongena. J. of Jap.Society of Hort. Sci., 59. (2): 358359.

Mohammed, S. T. M., Humidan, M., Boras,M. and Abdalla, O. A. 2009.Effect of grafting tomato on different rootstocks on growth and productivity under glasshouse conditions. Asian J. of Agri. Res., 3:47-54.

Panse, V. G. and Sukhatme, P. V. (1967). Statistical methods for agricultural workers. ICAR Publication, New Delhi(India).

Perez, J., Strange, M., Kaloshian, I. and Ploeg, A. T. 2006. Differential response of Migene-resistant tomato roots stock to root knot nematode. Crop Protection. 25: 382-88.

Rashid, M. A., M. M. Hossain, A. Rahman, S. Alam and G. C. Luther. 2005. Evaluation of grafting compatibility of cultivated eggplant and grafted tomato varieties on different Solanum rootstocks. http://www.avrdc.org.

Rashid, M. A., Rahman, A., Ahmed, B., Luther, G. C. and Black, L. 2004. Demonstration and pilot production of grafted eggplant and grafted tomato and training of farmers. http:// www.avrdc.org.

Sadasivam, S. and Balasubraminan, $\mathrm{T}$. 1987.Practical Manual in Biochemistry. Tamil Nadu Agriculture University, Coimbatore.

Sanjeev K., Patel, N. B., Saravaiya, S. N. and Vashi, J. M. 2016. Performance of grafted brinjal cv. Surati Ravaiya onto Solanum torvum Swartz rootstock under excess moisture conditions of south Gujarat, India. Int. J. of Trop. Agri., 34(3): 753-60.

Schwarza, D., Rouphaelb, Y., Collac, G. and Venemad, J. H. 2010.Grafting as a tool to improve tolerance of vegetables to abiotic stresses: Thermal stress, water stress and organic pollutants. Scientia Horticulture., 127:162-171.

Sherly, J. 2011. Studies on grafting of brinjal accessions (Solanum melongena L.) with wild solanum root stocks. Ph.D. (Hort.) Thesis, Tamil Nadu Agricultural University, Coimbatore.

Srivastava, R. P. and Kumar, S. 2002. Fruit and Vegetable Preservation: principles and Practices, 3rd ed. IBDC Publishers, Lucknow.

Turhan, A., Ozmen, N., Serbeci, M. S. and Seniz, V. 2011. Effects of grafting on different rootstocks on tomato fruit yield and quality. Horti. Sci., 38 (4): 142-149.

\section{How to cite this article:}

Satish Kr. Subba, Umesh Thapa, Pinkey Dukpa and Anant Tamang. 2021. Characterization of Solanum spp for Grafting and its Interpretation on Morphological, Production and Nutritional Quality of Fruit Under Polyhouse. Int.J.Curr.Microbiol.App.Sci. 10(10): 77-89. doi: https://doi.org/10.20546/ijcmas.2021.1010.011 